Open Access

\title{
Anticommunism in Korea and Germany in times of cold War
}

\author{
Gyoergy Szell(D)
}

Correspondence: gszell@uos.de School of Cultural \& Social Sciences, University of Osnabrueck, D-49069

Osnabrueck, Germany

\begin{abstract}
Besides several themes related to burning issues on the surface of the current discourses in South Korea, this special issue of the AJGES pays attention to the fundamental problems, which are essential to understand the unique character of South Korean society as a divided nation. The in-depth analysis of some fundamental mechanisms is indispensable to develop a long-term strategy dealing with the roots of various problems. A comparison with the history of Germany as a formerly divided country is deemed helpful in order to see the problems from different perspectives and broaden the horizon. The contributions of this Thematic Series were first published in Korean by Dolgebae, Paju in 2015.

Neben vielen anderen brennenden Problemen an der Oberfläche derzeitiger Debatten in Südkorea, widmet sich der Schwerpunkt dieser Ausgabe der AJGES einem grundlegenden Problem, i.e. der einzigartige Charakter der südkoreanischen Gesellschaft als einer geteilten Nation. Die Tiefenanalyse einiger der Mechanismen ist Voraussetzung, um eine langfristige Strategie zur Überwindung der Ursachen der verschiedenen Probleme zu entwickeln. Dabei ist der Vergleich mit einer früher geteilten Nation wie Deutschland zweifelsohne hilfreich, um die Probleme aus einer anderen Perspektive zu sehen und den Horizont zu erweitern. Die Beiträge in dieser thematischen Sektion wurden zuerst auf koreanisch vom Verlag Dolgebae 2015 veröffentlicht.
\end{abstract}

Keywords: Anticommunism, Cold War, South Korea, Germany, USA, Communism, Fascism

"A spectre is haunting Europe - the spectre of communism.

All the powers of old Europe have entered into a holy alliance to exorcise this spectre: Pope and Tsar, Metternich and Guizot, French Radicals and German police-spies."

(Karl Marx, and Friedrich Engels, The Communist Manifesto, 1848) ${ }^{1}$

"... also the theory becomes a material force, if it seizes the masses."

(Karl Marx)

\section{Background}

One of the main hypotheses to understand and explain anti-communism in modern history is first to understand and explain why and how modern communism appeared, i.e.:

(c) The Author(s). 2017 Open Access This article is distributed under the terms of the Creative Commons Attribution 4.0 International License (http://creativecommons.org/licenses/by/4.0/), which permits unrestricted use, distribution, and reproduction in any medium, provided you give appropriate credit to the original author(s) and the source, provide a link to the Creative Commons license, and indicate if changes were made. 
1. Without dialectics we do not understand anything.

2. Deep cultural and social structures are fundamental for the specificities of societies and their contradictions, i.e. without history we do not understand anything.

3. Capitalism produced economic, political, social, and cultural cleavages, which led to new political and social organisations, which organised uprisings, revolutions and other forms of resistance. I.e. without economics we do not understand anything.

4. Colonisation and imperialism have spread capitalist relations of production globally.

5. Nearly all, early communist experiments in the $19^{\text {th }}$ and $20^{\text {th }}$ century failed.

6. Deep social and cultural structures explain the specificities of communism and anticommunism in the world. There are nearly as many varieties of communism and anti-communism as countries.

7. Anti-communism is as old as communism.

8. In many countries the conflict between communists and anti-communists led to terrible civil wars.

9. The history of communism and anti-communism is full of contradictions and paradoxes.

10. There exists anti-communism even without communists.

11. The Soviet revolution from 1917 and the Soviet Union have casted the modern understanding of communism by creating the dogmatic Marxism-Leninism. ${ }^{2}$

12. The founding of the Soviet Union has changed world history, although it was really existing socialism and not communism.

13. The USA as hegemonic world power was and is the leader in anti-communism.

14. Japanese imperialism has as a counter-reaction promoted communism in East Asia.

15. West Germany and South Korea had developed specific forms of anti-communism due to their situation at the frontline between the two major powers.

16. The Korean War was the only international 'hot' war between communists and anti-communists since 1945.

17. Third World communism and anti-communism after the Second World War were in the centre of systems' competition between East and West, resulting in their division.

18. Although there are great varieties of capitalism, today's dominant form is the one of neoliberalism.

19. Anti-communism - like communism - is seeking political and cultural hegemony by all means.

20. The judicial system is utilized in both regimes (communist and anti-communist) to promote their interests.

21. The struggle between so-called communists and anti-communists gives limited academic freedom on both sides.

22. Most communist regimes and parties have disappeared since 1990.

23. Some socialist countries (e.g. China, North Korea, Cuba) survived the end of the Cold War (Saxonberg 2012).

24. Communism has changed into nationalism, actually there were already such elements from the very beginning.

25. Anti-communism is today largely replaced by anti-terrorism and anti-Islamism.

26. The recent interest in the study of anti-communism - more than twenty years after end of the Cold War in Europe - show the relevance of the topic also for future generations, especially for South Korea, where there is no peace and reunification yet. 
27. China with its Maoism as source of communism and target of anti-communism needs special consideration.

28. The future of humanity will be decided in China (Széll 2010a).

\section{On the theory of anti-communisms}

Certainly it will be necessary to differentiate between various forms of radical social movements: i.e. communists, socialists, anarchists, which are again spread in many political parties, tendencies and sects. These are in general amalgamated by anti-communist policies and ideologies, which also produce diverse forms of anti-communism, antisocialism, anti-Bolshevism (Generalsekretariat zum Studium des Bolschewismus 1975; Jakowlew 2004; Rebatet 1940) and anti-anarchism: reactionary, fascist, liberal, conservative. Nevertheless there are some basic principles also in the global context and in the long run (Braudel 1986), which justify the notion of 'anti-communism' as a heuristic approach. Nevertheless historic and cultural specificities, which sometimes go back thousands of years (Gurvitch 1962), have to be respected. For the context the following Fig. 1 may be helpful:

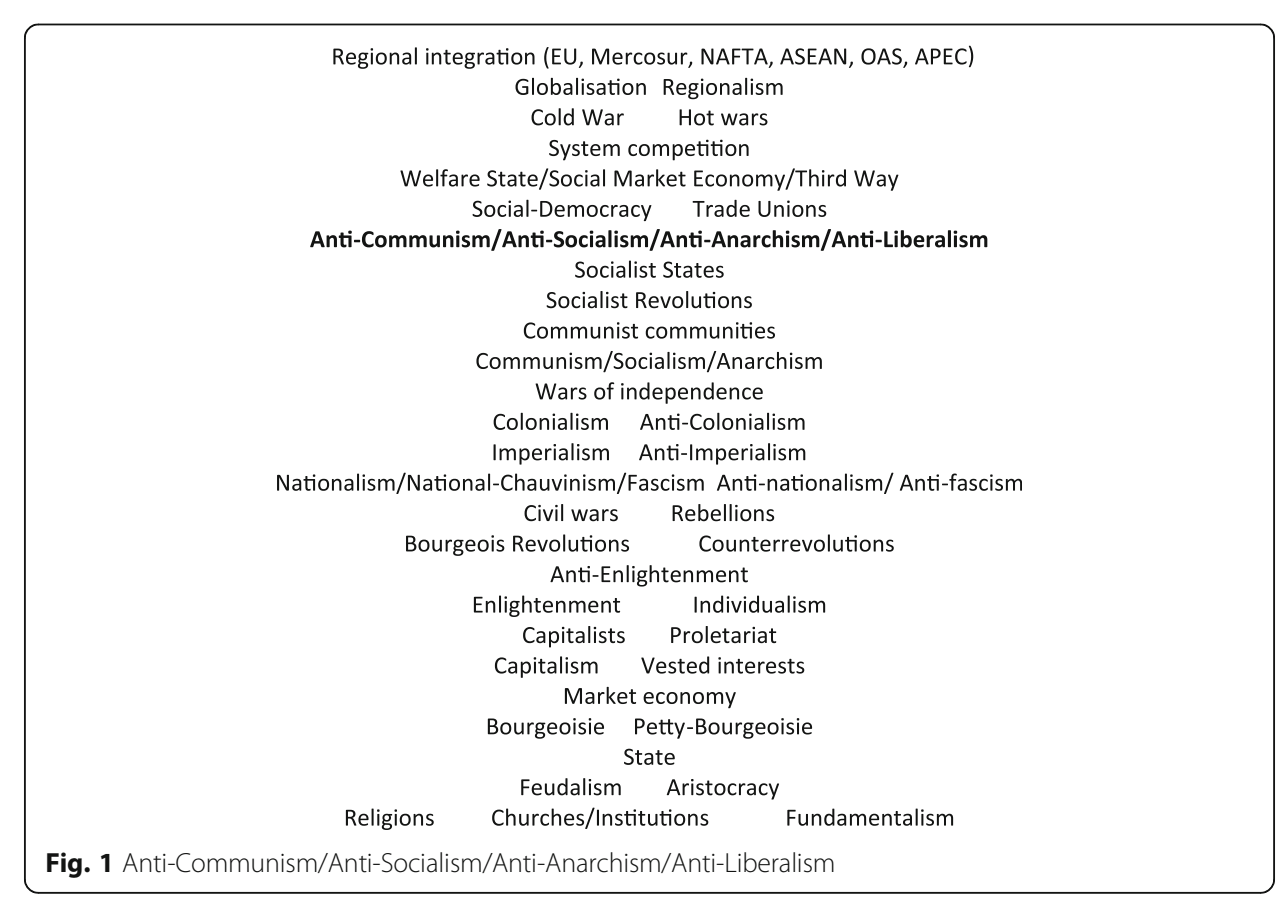

\section{Communism}

Before entering into a debate about anti-communism it seems to be necessary to define communism. ${ }^{3}$ Apparently this is an immense task, which cannot be done extensively (e.g. Tosel, André 2010). Why not just take the definition by the Collins English Dictionary (2013)?

1. "Advocacy of a classless society in which private ownership has been abolished and the means of production and subsistence belong to the community,

2. any social, economic, or political movement or doctrine aimed at achieving such a society, 
3. usually a political movement based upon the writings of Marx that considers history in terms of class conflict and revolutionary struggle, resulting eventually in the victory of the proletariat and the establishment of a socialist order based on public ownership of the means of production. See also Marxism, MarxismLeninism, socialism,

4. usually a social order or system of government established by a ruling Communist Party, esp. in the former Soviet Union,

5. often (mainly US) any leftist political activity or thought, esp. when considered to be subversive,

6. communal living; communalism."

As another easily acceptable and probably nowadays most widespread reference we may take Wikipedia (2013a). It distinguishes sixteen forms of Marxist communism and two non-Marxist ones (Table 1):

Table 1 Marxist and non-Marxist communism

\begin{tabular}{l} 
Marxist communism \\
Marxism \\
Leninism and Marxism-Leninism \\
Leninism \\
Stalinism \\
Trotskyism \\
Maoism \\
Prachanda Path \\
Hoxhaism \\
Titoism \\
Juche (Kim 1984) \\
Eurocommunism \\
Council communism \\
Left communism \\
Situationism \\
Autonomism \\
Non-Marxist communism \\
Anarchist communism \\
\hline
\end{tabular}

We can keep for our purpose some central elements:

1. Marxism is based on the methodology of Historic Materialism/HistoMat.

2. Although with a lot of revolutionary rhetoric, fundamentally communism has an evolutionary understanding of history: "In the womb of the old society the new society emerges." (Marx 1875)

3. Communism is based on social ownership (cooperatives, collectivism).

4. It has an anarchistic understanding of the 'withering away of the state'.

5. Communism did not militarily expand by itself.

6. 'World revolution' means parallel uprisings in different societies by its own contradictions - not a strategic overturn by a central agency or committee with its seat in Moscow. Nowadays this is completely out of time. 
Really existing communism occurred in local, utopian communities (USA, Brazil, New Lanark, Great Britain) and in the Kibbutzim since the $19^{\text {th }}$ century.

\section{Methods}

It may be surprising to find a lot of critical publications, conferences, media productions on the topic of anti-communism in the last couple of years (cf. e.g. The International Newsletter of Communist Studies; Wikipedia 2013b, c). There is a new generation of scholars, who practice some critical distance to Cold War attitudes (Greiner et al. 20062013). Many archives are fortunately opened, which allows to shed a new light on history. As the Cold War is the climax of anti-communism, it is worthwhile to pay specific attention to this period:

"The description of the history of the Cold War has entered since some time a new phase. An epoch designation of different length and importance - especially in German history often phases of a longer lasting East-west-conflict have been characterized - has become a fixed size, a defined historical unit, i.e. encompasses the period from 1945/47 until 1989/91 and presenting itself disciplinarily an own subfield of contemporary history. Cold War Studies have established themselves in the whole Anglo-Saxon world and beyond as research context. (Müller 2013; translation by Gy. Sz.)"

Gesine Schwan (1999) sees four forms of anti-communism for Germany:

1. Anti-communism of the social-democratic left,

2. liberal anti-communism,

3. anti-communism in the further bourgeois spectre of the bourgeoisie,

4. 'anti-democratic' anti-communism (National Socialism).

According to Kim Dong-Choon the bearers of anti-communism in South Korea are:

1. U.S trained intellectuals: anti-communism as liberalism,

2. Land lord class: anti-communism as class interests,

3. Christians and North Korean migrants: anti-communism as religion,

4. Pro-Japanese bureaucrats, police and Military: anti-communism for self-defensive logic or power politics,

5. Ordinary People: nti-communism for survival,

6. Traumatized people: anti-communism as social ill.

For the study of anti-communism we may differentiate four main schools:

- Traditional (Nolte 1974),

- Realist,

- Revisionist, and

- Post-revisionist (Vilmar, Fritz 1986).

And it may be worthwhile to study Commonsense anticommunism, as Jennifer Luff calls it (2012). The leader of the Communist Platform and leader of the opposition 
party in the Bundestag Die Linke, Sahra Wagenknecht, proposes a differentiation between hard and soft anti-communism (1994).

\section{Systematic approach}

For a better understanding I propose the following table (Table 2).

Table 2 Fields of analysis

\begin{tabular}{|c|}
\hline General \\
\hline - Functions \\
\hline - Structures \\
\hline - Interests \\
\hline - Legitimisations \\
\hline - Character \\
\hline - Forms \\
\hline - Effects \\
\hline Culture \\
\hline - Ideologies \\
\hline - Arts \\
\hline - Academia \\
\hline - Education \\
\hline - Media \\
\hline - Religion \\
\hline Politics \\
\hline - Intentions \\
\hline - Strategies \\
\hline - Tactics \\
\hline - Political parties \\
\hline - NGOs \\
\hline Society \\
\hline - Actors \\
\hline - Organisations \\
\hline - Civil society \\
\hline - Religious institutions \\
\hline Economics \\
\hline - Business \\
\hline - Unions \\
\hline The State \\
\hline - Institutions \\
\hline - Government \\
\hline - Administration \\
\hline - The Law \\
\hline - Police \\
\hline - Gender \\
\hline - Secret services \\
\hline - Military \\
\hline - Espionage \\
\hline
\end{tabular}


The issue

Anti-communism has a long tradition (Swennen 2010). Nobody is born as a communist or an anti-communist or an anti-Semite etc. We are made by socialization and specific circumstances to become or not to become one. Anti-communism started with modern communism, i.e. after the publication of The Communist Manifesto in 1848. In anticommunism there is quite often an intentional mix/amalgam of communism, socialism, anarchism, Marxism, Marxism-Leninism, Sovietism, syndicalism, Bolshevism, Stalinism, Russophobia, Maoism, Red Khmerism, Fidelism, Marxism-Horvatism/Titoism, and workers' self-management (for clarification cf. amongst others Anderson 1976; Bottomore 1983; Droz 1984).

Social and political revolutions are mostly nationalist so far: England, USA, France, Mexico, Germany, Hungary, Egypt, Russia etc. And most revolutions actually failed: Germany (1848, 1919), France (1848), Hungary (1919, 1956), and Russia (1905). There are also many revolts and rebellions (e.g. USA 1776), which do not end in a societal change, but promote the circulation of elites (Pareto 2006). Civil Wars happen since centuries, e.g. within the USA, Great Britain, Russia, Italy, France, India, Spain, Sudan, Yugoslavia, Indonesia, Vietnam, China, Myanmar, Yemen, Somalia, South Africa, nearly all of Latin America, Korea, Sri Lanka, Syria, Libya, Kurdistan, Africa (Cameroon, Congo, Angola, Mozambique, Somalia, South Africa, Namibia etc.). Since the $19^{\text {th }}$ century quite often communists/socialists/anarchists and anti-communists/anti-socialists/ anti-anarchists are opposed in these conflicts.

A schizophrenic relationship prevailed between East and West during the Second World War. No revolutionary situation in the West nor in Japan existed after Second World War, on which revolutionary movements could build on.

Probably The Black Book of Communism by Stéphane Courtois et al., published first in French in 1999, with a second volume in 2004, had since then the biggest impact on the anti-communist discourse (Courtois 2010; Courtois 2009; Courtois 2002; Courtois 2007; Courtois 2011): 26 translations and one million copies - however, surprisingly not yet in South Korea. One of the main arguments of the detractors of so-called communism, i.e. Soviet-style Marxist-Leninist regimes, are the hunger catastrophes, notably in Ukraine in the 1930s, the collectivisation in general and China in the 1950s, which are blamed to be deliberately produced by the regimes. As tragic and certainly also partly criminal these events are, they are definitely not by principle due to 'communism'. How many hungry people live today, even in the USA, Germany, South Korea, not to speak of the Third World? One billion altogether, and about 50 million die every year - mostly children (Right to Food 2013; Ziegler et al. 2011). That has nothing to do with communism, but with really existing capitalism. And if we go further back to colonialism, and hunger epidemies in Europe in the last centuries, we come up to billions as well. So, not surprisingly the answer came soon by Robert Kurz (1999) and Jean Surel-Canal (Suret-Canal 2002) with their The Black Book of Capitalism in German respectively in French. The Black Book on Colonialism by Marc Ferro in French followed in (2010). Interestingly all three have not been translated into English so far.

Perhaps the role of organized crime within anti-communism is one of the least researched issues, although it definitely has a most prominent place. The Italian and US-American mafias, the Japanese Yakuza, the Chinese triad and the Latin American drug cartels have great interest in fighting communism. That does not exclude that 
some communist groups - especially in Latin America - finance their operations through drug trafficking. And also during the Brezhnev era in the Soviet Union mafias grew enormously, until they controlled about $50 \%$ of the whole economy - until today. However, this does not contradict the earlier statement that organized crime is in general linked to anti-communism, as in the Soviet Union there existed no communism, but state capitalism, and real communists were persecuted.

Not to be neglected within the analysis of 'anti-communism' - as in many other circumstances - is paranoia: Not only Lenin, Stalin, Hitler, but all other dictators, and many US-Americans, Germans as well as Koreans suffered from this disease. Therefore the suspicions of conspiracy and treason are main elements within anti-communism. The foreigner, stranger, alien, enemy is often the 'barbarian' - a deeply rooted anthropological fear (Boveri 1960), which can be mobilized as well in anti-communism. Anti-communism is mostly a fight against an interior enemy, although the exterior enemy gives the pretext.

Also religion can serve anti-communism with the notion of the 'devil'. ${ }^{4}$ Communists were designated as 'Red devils'. And also another clerical notion comes into play here: heresy, i.e. falling away from the dominant belief system. Although witch burning has a long tradition in the USA - as well as in Europe, however, burning of communists did fortunately not happen. Specific fascist-religious, totalitarian organisations like Scientology (Hubbard 1956; Caberta 2007; Reitman 2011; Wright 2013) and the Moon sect (Wikipedia 2013f $^{5}$ played a large role in anti-communist activities.

Some politicians - as in former times kings and emperors - pretend to be selected by a supreme power to lead the people, to mission, to conquer, to fight the evil - i.e. communism. Recently amongst them were Ronald Reagan and George W. Bush in the USA (cf. to Széll in this volume). However, the main, driving ideology in the struggle against communism is nationalism with its notions of espionage and high treason. In its reactionary form it becomes national-chauvinism: "My country first!" The most radical form of nationalism is fascism - including racism and anti-Semitism. ${ }^{6}$

By the way, the statement of the late French President François Mitterrand in his last speech before the European Parliament in 1995 is unfortunately still valid: "Nationalism is war!" Today, interventions in other countries are legitimized as humanitarian. In the past they were bluntly justified as protecting own, mostly US-American interests without any UN-approval. Peace-movements were regarded as communist-led. But is peace not a fundamental Christian message?

\section{Capitalism}

The driving force of capitalism, as clearly elaborated by Karl Marx, is profit seeking and the accumulation of capital to be reinvested. The dominant sector is the financial capital (Hilferding 1981; Luxemburg 1972). It means the primacy of economics over politics. Today this orientation is expressed through the term of 'shareholder-value' (Vitols 2002). Crises are a fundamental element of the capitalist system (Lutz 1984; Marx 1976; Schumpeter 1928, 1943). And in the sense of dialectics they produce social uprisings, revolts, and revolutions. Mao Dze Dong characterized this phenomenon as the 'struggle of two lines'.

At the same time capitalism used the national framework to consolidate its power and nationalism as its ideology within the international competition. So varieties of capitalism developed (Hall, and Soskice 2001). However, again dialectically, 
independence wars began in the $18^{\text {th }}$ century: in the USA, Greece, Italy against the Austro-Hungarian Empire and the Vatican, the Balkans, in Latin America, Africa, Asia, i.e. nearly everywhere. These independence movements were quite often led by socialists, communists, anarchists et al.

In parallel, class struggles started everywhere too. Workers began to organize themselves in trade unions and political parties, which gained in many countries influence and power. Partly until today, they were fought by capitalists, conservatives, liberals and others through oppression, by law or by 'buying' them. One of the first and largely successful strategies was Taylorism (Taylor 1911). Later Fordism, i.e. the utmost division of labour linked to an increase of income for the working class, was weakening trade unions too (Braverman 1974; Aglietta, and Fernbach 2001). Now it is combined with 'sex, and shopping' and entertainment. This formula still expands, especially to the Third World.

But there is also another dimension: The exploitation of the Third World is corrupting the working class in the West, creating 'The affluent worker' (Goldthorpe et al. 1968-1970), distributing partly the extra-profits gathered there. Therefore the working class has become more sensitive for anti-communist propaganda, which is suggesting that its little wellbeing would be taken away by communists.

For sure modern capitalism has brought an enormous development of the productive forces, as already forecasted by Karl Marx. The price was imperialist and colonial wars, and again an increasing inequality. The dissolution of the agricultural societies led to urbanization and social change: individualization, atomization of society, precariousness, and big cities.

But as capitalism needed also the development of science and technology, the new class of scientific workers grew, and some of them became critical intellectuals. Dialectics again.

The global expansion of the capitalist mode of production was accompanied with human rights - but quite often also with religious, missionary campaigns. ${ }^{7}$ The free market should go hand in hand with democracy, the so-called Washington Consensus.

The social divide has increased in most countries, measured by the Gini-coefficient. The ultra-rich have the greatest fear of communism, socialism and welfare policies, buying politicians, media (Rupert Murdoch e.g.), churches, and scientists (Proctor, and Schiebinger 2008). They are in general the most anticommunist in our societies. But there is also a strategy similar to 'Big Brother' in Orwell's 1984, organising business in a totalitarian way: "I love my company." (Pagès et al. 1979)

The biggest financial and economic crisis of the $20^{\text {th }}$ century was the Black Friday in 1929. This catastrophe fuelled anti-capitalist movements - on the left and the right. The most recent global crisis since 2007/2008 provoked also anti-capitalist movements on the left and the right: the Occupy Wall-Street movement on the one side, nationalchauvinism and neo-fascism on the other side.

\section{Neo-liberalism}

Friedrich Hayek can be characterized as the leading neo-liberal, although today probably less well known than Milton Friedman, his disciple and winner of the Nobel Prize in Economics in 1976. For our topic this citation is of primordial relevance: 
"I am totally against dictatorships. But a dictatorship may be a necessary system for a transitional period. At times it is necessary for a country to have, for a time, some form or other of dictatorial power. As you will understand, it is possible for a dictator to govern in a liberal way. And it is also possible for a democracy to govern with a total lack of liberalism. Personally, I prefer a liberal dictator to democratic government lacking in liberalism." (Hayek 1981a: D9; citation according to Farrant et al. 2012: 521).

Already in 1933 Harold Laski wrote: "A capitalist democracy will not allow that its electorate by the hazard of an election will fall into socialism." (Laski 1933; Translation by Gy. Sz.) Historic examples have been the military dictatorship in Greece from 1967 to 1974 , and the intervention of the USA in Italy during the same period to prevent communists to be part of the government (Teodori 1998). Irony of the history: In 2013 a former communist has been elected Prime Minister of Italy.

If really existing socialism is 'organized irresponsibility' (Kornai 1986), what then about really existing capitalism?"One and only one social responsibility of business [is] to increase profits so long as it stays within the rules of the game, which is to say, engages in open and free competition without deception or fraud." (Milton Friedman in Capitalism and Freedom, University of Chicago Press, 1962; cited in Nelson, 2004: 14) And another citation from Milton Friedman in the same line: “... the notion of social justice is a completely empty expression, bereft of all determinable contents." (cf. Jorion 2013; translation by Gy. Sz.) Neo-liberalism in its practical implications to focus only on 'freedom' of the market (Friedman 2002) has liberated the destructive forces of capitalism.

\section{Really existing socialism}

The creation of the Soviet Union in 1917 was the biggest shock for capitalism in the early 20th century, and the capitalist nations tried to annihilate the Soviet Union through a civil war from 1918 to 1921 right away, but unsuccessfully. 'War communism' was the answer (Behrendt 2010). Against the rising danger of reactionary forces and fascism the Soviet Union launched the $I I I^{r d}$ Communist International, the so-called Komintern, in 1919 to assemble all organisations, which were ready to fight together for the survival and expansion of 'communism'. After its failure it was disbanded in 1943 (Kahan 1990).

Just to cut short: The Soviet Union was built on Tsarism, nationalism, and Statecapitalism (Linden 2007). The German social-democratic leader Wilhelm Liebknecht said in 1896: "Nobody has combatted State Socialism more than we German Socialists; nobody has shown more distinctively than I, that State Socialism is really State capitalism!" This assessment is confirmed by the notion of 'Socialism in one country' and the characterization of the defence against Nazism as the 'Great Patriotic War' in the Soviet Union.

The Soviet nuclear bomb established the balance of power between East and West, and led to a system competition since the 1950s. The central figure of the history of the Soviet Union was Joseph Stalin (Creuzberger 2009; Franklin 1972; Hofmann 1967; Kaplan 2006; Marcou 1988; Souvarine 1939), who ruled terribly from 1922 to 1953 and invented the notion of Marxism-Leninism. The Soviet Constitution was nearly perfect, but the reality not at all. The planned economy became a bureaucratic monster, called 
'barracks communism' (Busgalin, and Mayer 2008). The Hungarian economist Janós Kornai designates the Soviet system as 'organized irresponsibility' (1986, 1992), which certainly was one of the main reasons for its breakdown from within.

The Soviet Union united all elements of a dictatorship: no freedom of speech, no freedom of association, no freedom of press/media, and no freedom to travel. Millions of people, even top communist leaders, were imprisoned in concentration camps (Gulags) or murdered after show-processes. Paranoia on the side of the leaders and denunciation by many were characteristics of this system. The primacy of the party and its satellite organisations dominated over all other needs and functions. "The party is always right!", i.e. immunisation against any critique. ${ }^{8}$ This Soviet model served as scenario for George Orwell's book '1984'.

De-Stalinisation was started by Nikita Khrushchev after the death of the dictator, but Stalinism reappeared after the breakdown of the Soviet Empire. ${ }^{9}$ North Korea can be characterized as a Stalinist regime. Probably Lewis E. Kaplan was completely right with his book 'God Bless You Joe Stalin: The Man Who Saved Capitalism' from 2006. The radical reforms, which Mikhail Gorbachev tried with Glasnost and Perestroika, came much too late in 1985 (Manutscharjan 2009). The end of the Soviet Union in 1991 through a Coup d'État by Boris Jelzin, and supported by the West, was dramatic (Altrichter 2009; Brown 2004, 2010). Karl Marx had forecasted that a successful socialist revolution can only take place in the most developed societies. He seemingly was right (cf. also Dutschke 1974).

\section{Leftist Anti-Communism/Anti-Socialism/Anti-Stalinism/Anti-Dogmatism}

From the very beginning the anarchists fought communism (Kropotkin 1968; Fuëg 2000). Even before anti-communism spread in the West and the invention of fascism inner critique of the communist regime in the form of the Soviet Union developed from within. Originally the workers' and soldiers' councils - 'soviet' means 'council' made the revolution, which was transformed into the 'dictatorship of the proletariat' (Pankratowa, Anna 1976). Very quickly opposition arose not only from the side of the beaten Tsarists and Mensheviks, but very strongly also from within the Communist Party itself, where many felt the 'revolution betrayed'. This is the title of a book, written by Leon D. Trotsky in 1937. Trotsky was one of the leaders of the Soviet revolution, however, got soon in conflict with Stalin, and had to flee the Soviet Union. He was murdered by the KGB in Mexico in 1940 (Trotsky \& Leon 1937). But Trotskyism survived in the form of the $I V^{\text {th }}$ International.

Corruption was widespread in socialist countries. The 'Nomenklatura' - as the Yugoslav critique Milovan Djilas called it (1982) - lived in closed areas, kind of 'gated communities' like in the USA, with a lot of privileges. The Hungarian sociologists Agnes Heller, Ferenc Fehér, and György Markus characterized the Soviet Way as a 'dictatorship of needs and alienated everyday life' (1983). These three critiques emigrated after the failed Hungarian uprising of 1956 to the West. Andras Hegedus, Hungarian Prime Minister from 1955 to 1956, was another fierce critique of the Soviet system $(1976,1977)$. However, the most radical critique came from Rosa Luxemburg with her slogan "Freedom is always the freedom of the other!" (1972). These critiques were again criticized as revisionists by those in power (Wagenknecht 1994). 


\section{Fascism}

Fascism is the strongest anti-communist movement so far (Martens 1993; Nolte 1963, 1989; Nolte and Furet 1998). ${ }^{10}$ The notion Fascism was invented by Benito Mussolini in 1922. It builds on racism, xenophobia and especially anti-Semitism. It is a contradictory movement promising on the one hand 'eternity' (1,000 Year Reich) and on the other 'revolution'. With the Holocaust and the extermination of six million Jews, but also hundreds of thousands of gypsies and political enemies it was one of the most cruel and terrible political regimes in human history.

The Black Friday in 1929, where the New York Stock Exchange imploded, led to a world-wide financial and economic crisis with millions of unemployed in all capitalist countries. This misery strengthened fascist movements all over the world (cf. Table 2), offering an alternative to communism, therefore largely supported by the petty bourgeoisie (Franke 1988), but also by big capital (Polanyi 1957). A central element is the passive participation by the masses (Gorz 1987). Hate and distrust against everybody were the base of the system. By the way, the notion 'Fifth column' stems from General Franco during the Spanish civil war (Gross 1980: XV) (Table 3).

Table 3 Fascist regimes

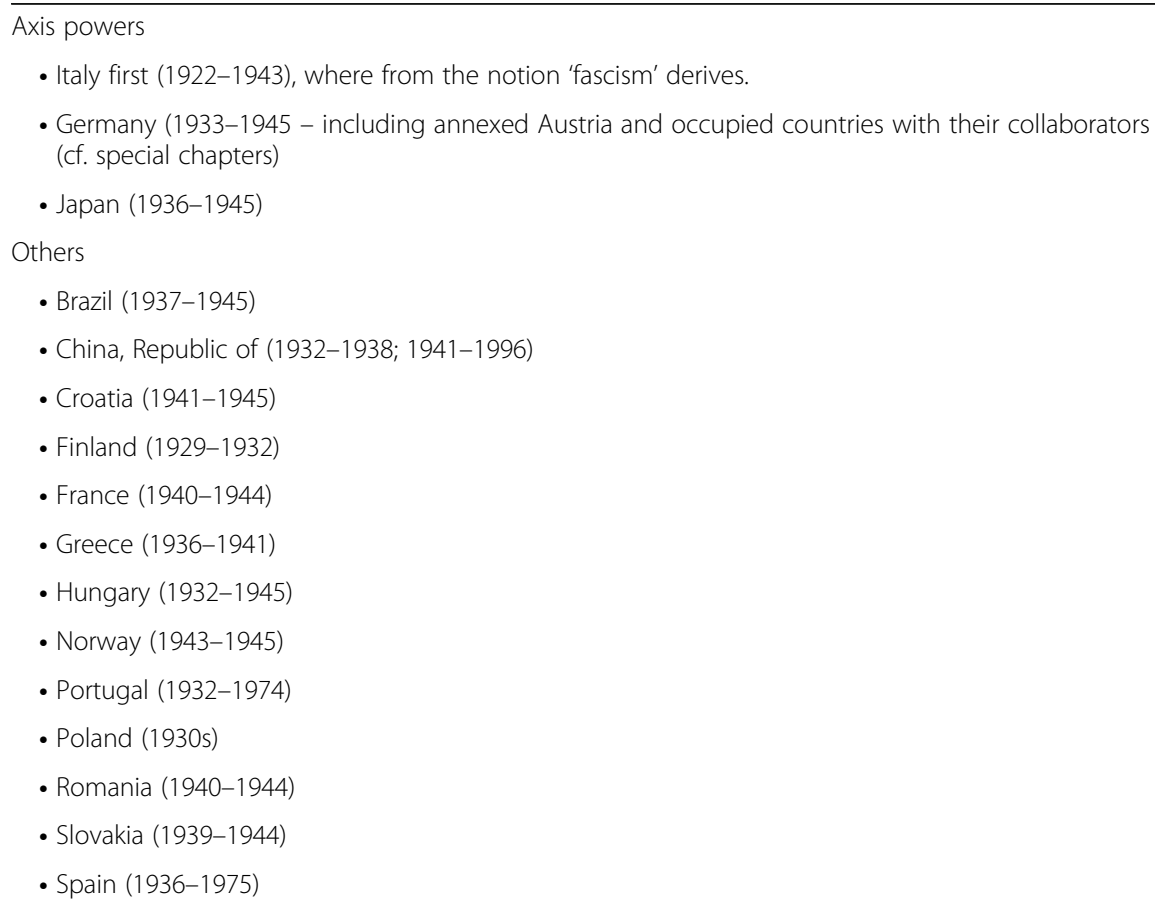

Anti-Communism is still strongest there, where there used to be fascist, reactionary authoritarian regimes/dictatorships, e.g. South Korea. At the same time anticommunism is paradoxically strongest there, where there are few or even no communists (similar to xenophobia).

The Second World War ended most fascist regimes by military defeat, co-ordinated by the then four Allies during the Teheran, Yalta, and Potsdam Conferences. Nevertheless some fascist regimes survived (Spain, Portugal). 
Fascism is, however, not yet dead, as neo-fascist movements and parties exist and become even stronger with the worldwide financial and economic crisis since 2007 - so in Germany, but also in Italy, Hungary, Belgium, the Netherlands, Norway and nearly all other European countries as well (Table 4).

Table 4 Essentials of conservative/fascist anti-communism

- Religion

- Nationalism/national-chauvinism

- Capitalism

- Free-market economy

- Vested interests

- Paranoia

- Heresy

- Xenophobia

- Racism

- Anti-international

- Distrust

- Anti-Enlightenment

- Anti-intellectual

- Anti-union

- Anti-workers

- Anti-peace

- Anti-social rights

- Anti-human rights

- Militarism

- Superiority-complex "God's own country!"

- Hate

- Family

- Anti-homosexuality

- Anti-abortion

\section{Anti-fascism}

Where there is fascism there is in the sense of dialectics also anti-fascism. As with anti-communism there are also different forms of anti-fascism, just to name the main:

1. Communism,

2. Socialism,

3. Anarchism,

4. Liberalism,

5. Traditional conservatism (wertkonservativ), and

6. Some religious groups.

As in the case of anti-communism it is an issue of consciousness, i.e. to regard fascism as a problem or a danger for one's own value system and life. 
The role of academia and intellectuals

The fundamental principle of science and culture in the modern world is Enlightenment. However, not all members of academia and intellectuals feel committed to it. The temptations of power and money are often too big for many not to resist or just being opportunistic. The German-Hungarian sociologist Karl Mannheim characterized intellectuals as free-floating (1936).

Until the age of Enlightenment religion dominated the value system. But the split between different religions and with it Weltanschauungen was certainly at the beginning of Enlightenment. Nevertheless Enlightenment has not yet become the dominant cultural phenomenon globally. On the contrary, fundamentalism is driving back this principle (Postman 1999; Széll 2001).

Science is neither neutral nor objective. In so far the struggle for cultural hegemony (Femia 1982; Gramsci 2000) is part of the overall political struggle. Historians describe the Dreyfus-affair in 1905 as the beginning of the modern intellectual, who was then at the left. But academia in general was part of the establishment, namely priests, doctors, lawyers and teachers. Actually, until the 1960s the majority of academics was employed in the public sector and had there to follow its strict rules.

When the Cold War broke out with its propaganda, psychological warfare, disinformation, and counterpropaganda many academics played - on both sides - a very prominent role, as we can see namely under McCarthyism. Ellen W. Schrecker describes this as 'Cold Civil War' (1986: 129). And Stefan Creuzberger designates it as 'Cold War Culture' (Creuzberger 2009: 38). The leading US-American sociologist, Talcott Parsons, contributed also by his theory to anti-communism. The refusal of class theory was also part of the intellectual struggle against communism and Marxian thinking and methods.

A historic compromise was reached in the 1960s, when pluralism was propagated, i.e. that different schools are allowed, even demanded in teaching, in the public, in the media. It is regarded together with the plurality of the party system as a basic element of democracy. But this pluralism can be misused, when a tiny minority (backed by big capital) demands the same rights of audience and representation - e.g. in the case of climate change - as the overwhelming majority of scientists. Robert N. Proctor and Londa Schiebinger call this 'agnotology', when the denial of facts is systematically pursued (2008). Although we have to acknowledge that in the past scientific revolutions as other revolutions as well - were always started by a minority (Kuhn 1982).

We arrive now at the issue of theory and praxis. Theories are the basis of Enlightenment and should explain the world, and by this give us guidance to improve it. So, there is a dialectical relationship between theory and praxis. "Thoughts are free." This is another basic element of democracy, but not if you organize yourself to propagate your - communist ideas to attain power. In the case of Scientology this freedom is unlimited in the USA, therefore the USA stigmatise European countries, which prohibit Scientology, as 'undemocratic'.

\section{The media and arts}

The freedom of opinion and with it of media and arts is fundamental for a free society and democracy too. The media are even called the fourth pillar of a democratic society. The role of literature, movies, TV and arts within anti-communism has not been 
treated enough so far, and unfortunately will not be treated in this volume as well, although their impact is not be underestimated in an entertainment society.

\section{Totalitarianism}

Probably the most successful anti-communist strategy during the past decades is the notion of totalitarianism (Wikipedia 2013d). It means the identity of fascism and communism, i.e. that their form and content - one-party rule, authoritarian leadership (Der Führer), strong ideology, oppression of any freedom, concentration camps, lack of justice, collectivism - are identical (Széll 1992a). On the ideological front George Orwell with his books '1984' and 'Animal Farm' (Orwell 1945) contributed much to the spreading of the totalitarian thesis (Széll 1985). Also Aldous Huxley's 'Brave New World', already written in 1932, became a standard reading in this vein - with translations into nearly all languages and dozens of editions since (Huxley 1960). The book The Origins of Totalitarianism by the German-American philosopher Hannah Arendt from 1951 had the biggest impact on this debate (cf. also Friedrich, and Brzeziński 1956; Friedrich, Curtis, and Barber 1969). Friedrich Hayek introduced the notion of 'Totalism' to cover communism and fascism. However, if we look back into history, all pre-modern societies were totalitarian. The religious institutions and monarchic rules prevented all freedom of an individual. The notion of individual was even not existent.

In modern times a number of renegades from communist parties, Stéphane Courtois (2003, 2006a, b) and David Horowitz are two of the most prominent ones, became the strongest anti-communists. The critique of totalitarianism from the left argues mainly that there is a qualitative difference between really existing socialism and fascism: Really existing socialism imploded at the end by its own inner contradictions, and transformed itself peacefully into democratic societies (Schmeitzner 2007; Traverso 2001). However, this may not be fully true: Fascists regimes in Spain, Portugal and Greece transformed themselves into democracies in the 1970s. Whereas after the end of the Soviet Union Russia and most former Soviet Republics remain authoritarian states.

\section{Results and discussion}

To understand the differences of anti-communism in the different parts of the world, and notably the Third World we have to go back to the 'deep structures' of society, including culture and religion.

\section{United States of America}

For sure the USA are the main protagonist of anti-communism since a century, notably after the demise of fascist regimes. More will be explained in another article in this thematic series.

\section{Europe}

Apparently the diversity of Europe with 47 nations is so great, and its history and culture are so manifold, that it is absolutely impossible to give here - also due to the limited space - an overview on anti-communism over the last two hundred years on this continent. In the $19^{\text {th }}$ century in every country social movements, trade unions, communist and socialist parties emerged, fighting capitalist exploitation and 
imperialism. We can find therefore all kind of historical, political and cultural variations. The role of the Soviet Union and its Marxism-Leninism for the development of really existing socialism, i.e. state capitalism, and anti-communism and fascism as counter-strategies was discussed above (Polanyi 1944). After Wold War II the Soviet Union enlarged its satellite system with the Warsaw pact and the COMECON to cover the whole of Eastern and parts of Central Europe.

The Spanish Civil War (1936-1939) was the second hot confrontation between socialists/communists/anarchists and anti-communists on the continent - after the war in the Soviet Union from 1918 to 1921 -, which this time the anti-communists won. Their Anti-Komintern-pact from 1936 has to be mentioned too. ${ }^{11}$ Many regimes in Europe during the interwar period were anti-communist or directly fascist. And anticommunist military dictatorships continued after the war in Spain and Portugal. With the help of the USA the military dictatorship was resumed in Greece from 1967 to 1974.

Hence, we also have to structure the period into different phases, according to the changing international and national conditions. The division of Europe and namely Germany through the Iron Curtain from 1948 to 1989 was the most remarkable structure. This period of the confrontation of the two super-powers and their allies within their respective defence-alliances (NATO and the Warsaw-Pact) was called Cold War in contrast to what happened on the Korean peninsula (cf. Dijk et al. 2008). ${ }^{12}$

The popular up-risings in the GDR in 1953, in Hungary and Poland in 1956, the Prague Spring in 1968, and again in Poland in 1981, led to many refugees to the West, and strengthened by that anti-communist propaganda and feelings. On the other hand it has to be recognized that all of these movements were in the long run important steps for the democratization of these societies. In 1975 the so-called Helsinki Process started to overcome slowly Cold War-structures in Europe.

At the same time it has be mentioned that there were quite strong, legal communist parties in France and Italy, which won in elections until the 1980s up to $25 \%$ of votes. And after the end of the military dictatorships in Spain, Portugal and Greece the legalized communist parties there have still quite some influence until today, because they were a major element of the social movements against the dictatorships.

After 1990 in many former socialist countries new and old anti-communist movements and parties started and took power in most of them - at least temporarily. ${ }^{13}$ Actually about $30 \%$ of Europeans are xenophobic, with a tendency to the extreme right and with it to anti-communism (ENAR 2013), and this is true even amongst students (Kassis, and Schallié 2013). One explanation for the latter may be the mostly conservative academia everywhere - since centuries (Evola 2008; Montalbano 1987). The most shocking event of an anti-communist amok was the Norwegian Anders Behring Breivik, who - in 2011 - murdered hate-driven 77 innocent people, nearly all of them socialist teenagers (Borchgrevik 2013; Wikipedia 2013h). This was more surprising, as Norway is ranked as the most democratic country in the world, but at the moment of the amok the extreme right had already an audience of $20 \%$ of the population during elections.

But fortunately Europe has also a better part in regard to communism. The communists in East and West were fundamental in bringing down the Nazi-regime, and also the military dictatorships in Western Europe. For many decades they played a very constructive part in rebuilding Europe within a historic compromise. The characters Don Camillo and Peppone by the Italian author Giovannino Guareschi (1908-1968) show 
this relationship in a humoristic way. Certainly due to this approach, these novels and movies had an enormous success all over Europe (Wikipedia 2013g).

After the breakdown of the Soviet Empire, however, practically all European communist parties transformed themselves into social-democratic parties (Euro-communism). In this context we have also to discuss the role of communist trade unions and its World Federation in Prague until 2006, when they merged with the International Confederation of Free Trade Unions into the International Trade Union Confederation/ ITUC. Within the European Trade Union Confederation/ETUC there were always all kind of anti-communist trade unions as members until 1999 - when the French communist C.G.T., the biggest one, joined it. Dialectics were at play, when three movements for a 'Third Way', i.e. between socialism and capitalism, were experimented (Wikipedia 2013e), but did not end successfully so far:

1. In Yugoslavia from 1945 to 1991 with its self-management-socialism (Széll 1992b; Tito 1960),

2. The Prague spring in 1968 (Sik 1976), and

3. Anthony Giddens' attempt to overcome casino capitalism since 1998. He managed to solicit the support by Bill Clinton, Tony Blair, Romano Prodi and Gerhard Schröder (Giddens 1998). Nevertheless this project failed, because unregulated capitalism was stronger (Soros 1998).

"The convergence theory, in history and sociology, states that all industrial systems, whether capitalist or communist, would converge in their social, political and economic systems because of the determinant effects of technological development." (Encyclopedia 69.com 2013) So the hope of the convergence theory, developed in the 1970s, did not realize.

\section{Great Britain}

In regard to anti-communism Great Britain played a central role in the European context. Although Karl Marx and Friedrich Engels found refuge from continental prosecution in London, and although there is a rather strong labour movement, Britain is a bulwark - especially in these days - of finance capitalism. Anglo-Saxon co-operation during World War One and Two, and beyond is still - as recent NSA-scandals demonstrate - a solid basis for hegemonial strategies. Prime Minister Winston Churchill was one of the major driving forces for the Cold War (cf. Ruotsila 2001, 2005). A special task was assigned to the information research department 1945-1953 (Defty 2004).

\section{France}

France is in regard to the history of communism and anti-communism preponderant. Karl Marx and many other communists, socialists and anarchists found refuge in Paris in the 1840s. The most important event for communism in the $19^{\text {th }}$ century was without doubt the Paris Commune in 1870/71. Germany and France were at war, nevertheless it was more important for them to destroy this first Communist government together than to continue warfare for a while. The Commune was much more related to Pierre J. Proudhon's federalist ideas (Proudhon 1969) than those of Karl Marx. From 
the abundant literature on the subject here just a choice: Guérin 1966; Haupt 1979; Lefebvre 1965; Lissagaray 1969; Marx 1871a, b; Marx et al. 1968.

From 1936 to 1939 a leftist government ruled under the heading Popular Front, which realized a lot of workers' demands, and where communists had some influence (Lazar 2005). The communist Henri Lefebvre saw already in 1938 the terrible results of the first five years of Hitler's reign. The French Communists were the backbone of the French Résistance, and therefore participated at the first after-war government under Charles de Gaulle. After the end of the Second World a number of non-dogmatic, non-Stalinist groups and networks developed, which played quite a role in the May 1968 uprisings and have quite some impact until today. The group Socialisme ou Barbarie with its own review was one of its most influential. Already before the breakdown of the Soviet Empire communist parties and movements were in a deep crisis (Weisz 2011).

However, the Cold War strengthened anti-communism in France as well, because it has not to be forgotten that millions of French were collaborators with the Nazis under the Vichy-regime (Bloyet, and Sauvage 2005; Lejeune 2003; Sanders 1988). The extreme right is today the main force of anti-communism in France and organised itself as Front National since three decades (Moch 1978). The extreme right has altogether an audience of some $20 \%$. Various leftist parties gathered together during the first round of the presidential elections in 2012 some $15 \%$ of votes. So, there is still space for anti-communism.

\section{Other European countries}

There is no room here to discuss anti-communism in all the remaining 45 European countries. A special case may, however, be Switzerland (Thur 1937). As a neutral, basic democratic country in the heart of Europe it unites all features of a perfect democracy, although it is only at seventh place in the democracy index. But anti-communism was always and is still very present (Caillat 2009). In Europe ten monarchies - and we should add the Vatican, which is a religious state, - continue and therefore are not fully democratic. By definition even a constitutional monarchy cannot be a full democracy as the head of state is hereditary and not elected. ${ }^{14}$ In many countries, although most privileges are abolished, the old aristocracies remain still very powerful. They transmit their influence and wealth through heritage. So, all monarchies and aristocracies are anti-communist by their constitution and interests. And that is why communists abolished the monarchy, wherever they could.

\section{The Third World}

After the imperial expansion of European powers during Early Modern Times, the whole world was colonized with a few exceptions (Ethiopia, Japan, Korea, Yemen). This distribution of the world was settled by the then superpowers during the Berlin Congo Congress in 1884/1885. In the Third World the communist government in Kerala, Southern India, was the first to be freely elected in the 1950s. It remained in power until recently, and Kerala is the most literate and conflict-free state of the Indian Union. Later West-Bengal with Calcutta as its capital - the biggest city and one of the most populated states - joined the communist governments. 
Communist regimes in the Third World were established as a counter-movement against colonial domination and exploitation. Herbert Marcuse set his hope for the liberation of man on the Third World (1964). In the struggle for independence a large number of countries, supported by the Soviet Union, declared themselves socialist. Many global anti-communist struggles, conflicts and wars were fought there, and resounded in the Western societies. The main setback for anti-communism was the loss of China to the communists. However, today the main ideology of the People's Republic of China is Confucianism and not Maoism anymore, accompanied by nationalism - as in most of the countries of the world (Bell 2010). For the debate about anti-communism in the international context Yugoslavia and other non-allied countries (cf. the Bandungconference in 1955) in their demand of a 'Third Way' had quite some impact.

Latin America freed itself largely already in the $19^{\text {th }}$ century from colonial rule; Asia and Africa followed in the second half of the $20^{\text {th }}$ century. In the Southern hemisphere Latin America was regarded as the backyard of the USA as expressed in the Monroe doctrine. The loss of Cuba in 1959 was the first setback for the USA in this part of the world. Actually as later in the cases of Peru, Chile, Nicaragua, Venezuela, Bolivia and Grenada the revolutionaries were just looking for more social justice, they were no communists at the beginning. They were made to become communists and driven into the arms of the Soviet Union by the counter-strategies of the USA. In Latin America military dictatorships in Argentina, Brazil and Chile were actively supported by the USA. Chile under Pinochet became even a model for neo-liberalism (cf. Hayek above; and Palacios 2009). The killing of Che Guevara in Bolivia in 1967 was a great success for anti-communism for the decades to come, as well as the stop of the very successful Popular Participation Programmes/PPP of the United Nations, where democratic participation was experimented on a large scale (1971).

So, counterrevolutions led by the USA started in the 1960s (Horowitz 1967), in Latin America as well as in East Asia. After the French lost Indochina in the 1950s Cambodia, Laos and Vietnam - which was divided for many decades -, the USA stepped in according to the Domino theory, i.e. that the USA had to prevent that one state after the other falls into the orbit of the communists, in this case the Chinese.

The Red Khmer gave a good pretext to fight them. They committed one of the most terrible genocides, killing about a quarter of a population of eight million in the 1980s (Becker 1998; Kiernan 2004). It is doubtful, if this return to primitive communism has anything to do with communism. Nevertheless it strengthened anti-communism in the West and also in the respective countries. Today Cambodia, Laos and Vietnam as well as Myanmar are reintegrated into the capitalist world market. Although the USA and capitalism had lost the wars there, it has won the peace.

In Africa the hot Cold War continued especially in the former Portuguese colonies of Angola and Mozambique, but also in former Belgian Congo, with their enormous natural resources. Although the disappearance of the Apartheid regime in South Africa, one of the most anti-communist in the world, was a serious blow to US-hegemony, neo-colonialism in Africa was continued also by France and Great Britain (Ferro 2010).

The Arabian authoritarian, monarchic states (namely Saudi Arabia etc.) are other bulwarks of anti-communism and therefore largely US-supported. They export religious fundamentalism, which is a collateral damage - created by the USA. Take as an 
example the 'War against terror'. Actually the Taliban, who were financed by the CIA in the fight against the Soviet Union, are now the most dangerous enemy.

Japan

Anti-communism in Japan had in general - except for the period of the Komintern before the Second World War - no direct link with German anti-communism. Only McCarthyism was shared later. The main basis for anti-communism today is the past and on-going territorial conflicts with China and North Korea. Also the conflict with the Soviet Union about the fate of the Kurile Islands was feeding anti-communism, and has prevented a peace treaty until now. The imperialist colonial and colonial wars since the 1880s - following the Western model - led to the annexation of Taiwan and Korea, as well as large parts of East Asia until 1945.

Due to long-time isolation $50 \%$ of Japanese are xenophobe, and a strong tendency for the extreme right - the highest rate of Western democracies (Schreiber 2013). A basis for anti-communism too. In 1948-1951, in the period of American occupation, a 'red purge' occurred in Japan, in which over 20,000 people - accused of being Communists - were dismissed from their jobs (Tetsuo, and John W. Dower 2006). Strong anti-communist organisations are still active, often linked to organized crime, i.e. the Yakuza.

Nevertheless the US-American Douglas Moore Kenrick published the book 'Where Communism Works. The Success of Competitive Communism in Japan' in 1988. He argues that the Japanese social structure and the company are based on the Ie-principle, i.e. the rice growing community, which has communist features (cf. also Széll 2001; Yazawa, Shujiro 2009). But for sure these elements are quickly fading away (Széll, and Széll 2009).

\section{Conclusion}

\section{Anti-communism in the Korean context ${ }^{15}$}

Since Germany's unification in 1990 and the end of Cold War in Europe certainly anticommunism still survives, but has changed and lost a lot of its impact. However, 'anticommunism' under the circumstances of the Cold War system is still one of the most important keywords to understand the background of the specific development of South Korean society (Gills 1996). The division of the Korean nation (1945/1948), the Korean War (1950-53) - which also was a civil war about competing ideological systems - and the specific historical experience of extreme ideological confrontation produced a relatively homogeneous ultra-rightist society in South Korea, where anticommunism was internalized by the huge majority of society as a 'pseudo-consensus'. In this extremely violent process almost all left-wing groups and their members were exterminated and those, who survived, and the bereaved were to be silenced. These historical collective traumata were massively suppressed until 2004. The traumata, which did not have the opportunity to be healed, might be the reason for the present uncompromising socio-political ideological conflict in South Korea, which has been called in recent time as 'South-South Conflict'.

Even though the anti-communist resentment has been weakening in the course of democratization, which was contested by the dualistic view of Cold War mentality (either 'we' or the 'enemy'), South Korea has been still ruled by 'war-politics' as named by Kim Dong-Choon. It means, even though the doctrine of rule of law, liberal democracy 
and constitutional rule are institutionalized, the principles of war or militarism have penetrated in all parts of society and the state, and have still been working as every-day affair even in the form of rule of law. The political measures taken by the Lee MyungBak administration (2008-2013) in relation to candle-light demonstrations, investigations of donations of some NGOs by the National Intelligence Service, the inspection of citizens by military secret service or, in general, the partly excessive application of the National Security Law are only several examples.

Especially during the military dictatorship, in the phase of state-led, condensed economic development, anti-communism served as an important power mechanism to discipline the citizens and mobilize them to achieve the developmental goals set by the state. Hyo-Je CHO, another South Korean sociologist, has described the specific character of South Korean society as an 'anti-communist regimented society' coined by the 'Statist Developmental Mobilization Regime'.

Linking up the three principles - 'anti-communism', 'authoritarian state' and 'economic growth' - played a key role in the understanding of South Korean society from the 1960s until the 1980s, and its consequences also marked the later period. On the one hand, anti-communism was an indispensable support for the dictatorship and created the absolute predominance of the state over civil society. On the other hand, in the context of the ideology of growth anti-communism guaranteed the absolute predominance of capital over labour. These structural imbalances ensured the reproduction of the existing political-economic set-up with a structural advantage for conservative or even ultra-right-wing groups.

In the course of democratization, the role of civil society has been reinforced and, especially under the government of late President Roh Mu-Hyun, many organizations even obtained the opportunity to participate in the policy process. However, the intensification of neo-liberal policies during the Roh administration and thereafter has even strengthened the predominance of capital over labour. Neo-liberalism has been a worldwide phenomenon for the last decades, but in Korea it could be backed by anticommunism in the context of national division, on-going Cold War system and warlike state (i.e. under the armistice).

The 'Hermit kingdom' tried to remain - like Japan - for centuries outside of the Western influence. The Japanese occupation since 1910 led to modernisation, AntiJapanism and pro-communism. Korea liberated itself from Japanese occupation, under the leadership of Kim Il-Sung - not by the Soviet Union. Nevertheless the role of Confucianism in regard to anti-communism has still to be determined. Certainly the strongest anti-communist influence in South Korea came through the US occupation after 1945 and after the war between 1950 and 1953. Until today - as long-time for Germany - the US political system remains dominant. It is even more expressed through the military dictatorships until the end of the 1980s. And the Korean diaspora in the USA is not be neglected in this context. The result is a strongly divided country, as the free elections since more than 20 years show (cf. Shin 2005; Song, and Werning 2012; Széll 2010b, 2012). The role of Chaebols, although an issue in the last presidential election, is not to be diminished. There remain two trade union-federations, which are fiercely opposed. There is a weak civil society and lack of political culture (Lee 2007). Anti-North Koreanism is one of its products (cf. the article by Hyo Je Cho). On the other side we find an increasing anti-Americanism, to be seen around the Free Trade Agreement-negotiations. 


\section{Endnotes}

${ }^{1}$ Interestingly UNESCO declared The Capital by Karl Marx as World Cultural Heritage.

${ }^{2}$ Definitely Karl Marx was never a 'Marxist'.

${ }^{3}$ Actually we may even go back to utopias since antiquity (communist utopias, early Christianity; Thomas More).

${ }^{4}$ The Catholic Church was especially violent, cf. e.g. the Encyclica Quadragesimo (15 May 1931), although the early Christian communities were communist.

${ }^{5}$ The link to Korea is quite interesting in this context.

${ }^{6}$ Although, as we will see later, really existing socialism propagated and propagates nationalism as well.

${ }^{7}$ Today most strongly in the form of the Pentecostal churches, notably in South Korea, Latin America, South East Asia and Eastern Europe.

${ }^{8}$ This reminds of the infallibility of the Pope.

${ }^{9}$ Anti-Stalinism was criticized by Anton Kaute (2005), and Kurt Gossweiler (2005).

${ }^{10}$ For a critique of the latter cf. Traverso 2001.

${ }^{11}$ It had a predecessor with the Bureau Permanent de l'Entente Internationale contre la III Internationale $(1929,1934)$.

${ }^{12}$ Although mostly forgotten, there raged, however, a terrible civil war in Greece from 1946 to 1949.

${ }^{13}$ The case of Hungary is an extreme one, where after the elections from 2011 the two extreme right-wing parties won $75 \%$ of votes. The situation in many Western countries is also alarming in regard to anti-democratic movements and non-democratic government actions.

${ }^{14}$ In so far I doubt the ranking by the Economist, which has it seat in a monarchy. Strange is also the characterization that the USA is a full democracy, but not France. In this ranking there are only 25 full democracies amongst 167 nations. North Korea is at the end.

${ }^{15}$ The specificities of anti-communism in South Korea are well treated in other articles in this thematic section. Here it is only worthwhile to mention that the main difference between Germany and South Korea is that Germany has been the aggressive power - like Japan - during World War Two and Korea the victim.

Competing interests

None.

Funding

Friedrich Ebert Stiftung.

Received: 20 May 2016 Accepted: 20 January 2017

Published online: 04 March 2017

References

Altrichter, Helmut. 2009. Russland 1989. Der Untergang des sowjetischen Imperiums. München: C.H. Beck

Anderson, Perry. 1976. Considerations on Western Marxism. London: New Left Books.

Becker, Elizabeth. 1998. When the War Was Over: Cambodia and the Khmer Rouge Revolution. New York: Public Affairs Pr. [1986], revised edition.

Behrendt, Lutz-Dieter. 2010. Kriegskommunismus, Historisch-kritisches Wörterbuch des Marxismus vol. 7/I. eds. Wolfgang F. Haug et al., 2043-2056. Hamburg: Argument Verlag

Bell, Daniel A. 2010. China's new Confucianism: politics and everyday life in a changing society. Princeton/N.J: Woodstock, Princeton University Press [first ed. 2008].

Bloyet, Dominique, and Jean-Pierre Sauvage. 2005. La répression anticommuniste en Loire-Inférieure. La Crèche: Geste Ed. Borchgrevik, Aare. 2013. A Norwegian Tragedy: Anders Behring Breivik and the Road to Utoya. London: Polity. 
Bottomore, Tom (ed.). 1983. A Dictionary of Marxist Thought/DMT. Oxford: B. Blackwell.

Boveri, Margret. 1956-1960: Der Verrat im XX. Jahrhundert. Reinbek bei Hamburg: Rowohlt, 4 vols.

Braudel, Fernand. 1986. Afterthoughts on material civilisation and capitalism. Baltimore/MD: John Hopkins University Press. Braverman, Harry. 1974. Labor and Monopoly Capital. The Degradation of Work in the Twentieth Century. New York:

Monthly Review Press.

Brown, Archie. 2010. The Rise and Fall of Communism. New York: Vintage.

Brown, Archie (ed.). 2004. The Demise of Marxism-Leninism in Russia. London: Palgrave.

Bureau Permanent de l'Entente Internationale contre la III Internationale. 1929. Une nouvelle querre mondiale :

"La guerre bolchéviste ». Publié à l'occasion de la Vle Conférence du Conseil International de l'Entente internationale contre la III $^{\mathrm{e}}$ Internationale. Genève.

Bureau Permanent de l'Entente Internationale contre la III Internationale. 1934. Le Komintern, le gouvernement soviétique et le Parti Communiste de l'U.R.S.S. Genève.

Busgalin, Alexander, and Mayer Günter. 2008. Kasernenkommunismus, Historisch-kritisches Wörterbuch des Marxismus vol. 7/l. Eds. Wolfgang F. Haug et al., 407-411. Berlin: Argument Verlag.

Caberta, Ursula. 2007. Schwarzbuch Scientology. Gütersloh: Gütersloher Verlagshaus.

Caillat, Michel (ed.). 2009. Histoire(s) de l'anticommunisme en Suisse. Zürich: Chronos,

Collins English Dictionary. 2013. Communism <http://unw.collinsdictionary.com/dictionary/english/communism> [19 August 2013].

Courtois, Stéphane (ed.). 2010. Das Handbuch des Kommunismus: Geschichte? Ideen? Köpfe. München: Piper.

Courtois, Stéphane. 2009. Communisme et totalitarisme. Paris: Perrin.

Courtois, Stéphane (ed.). 2002. Du Passé faisons table rase! Histoire et mémoire du communisme en Europe. Paris: Robert Laffont.

Courtois, Stéphane (ed.). 2003. Une si longue nuit. L'apogée des régimes totalitaires en Europe, 1935-1953. Monaco: Éditions du Rocher.

Courtois, Stéphane (ed.). 2006a. Le Jour se lève. L'héritage du totalitarisme en Europe, 1953-2005. Monaco: Éditions du Rocher.

Courtois, Stéphane (ed.). 2006b. Les Logiques totalitaires en Europe. Monaco: Éditions du Rocher.

Courtois, Stéphane (ed.). 2007. Dictionnaire du communisme. Paris: Éditions Larousse.

Courtois, Stéphane (ed.). 2011. Sortir du communisme. Changer d'époque en Europe. Paris: Presses Universitaires de France.

Courtois, Stéphane, et al. 1999. The Black Book of Communism: Crimes, Terror, Repression. Cambridge/MA: Harvard University Press.

Creuzberger, Stefan. 2009. Stalin: Machtpolitiker und Ideologe. Stuttgart: Kohlhammer.

Defty, Andrew. 2004. Britain, America and anti-communist propaganda 1945-1953: The information research department. London et al.: Routledge.

Dijk, Ruud van, et al. 2008. Encyclopedia of the Cold War. New York: Taylor, and Francis.

Djilas, Milovan. 1982. The New Class: An Analysis of the Communist System. New York: Mariner Books. 1957.

Droz, Jacques. Ed. 1984. Geschichte des Sozialismus. Frankfurt a.M., Berlin, and Wien: Ullstein, 17 vols.

Dutschke, Rudi. 1974. Versuch, Lenin auf die Füße zu stellen. Über den halbasiatischen und den westeuropäischen Weg zum Sozialismus. Berlin (West): Wagenbach.

Encyclopedia 69.com. 2013. Convergence Theory <http://www.encyclopedia69.com/eng/d/convergence-theory/ convergence-theory.htm> [1 August 2013].

European Network Against Racism/ENAR. 2013. Recycling Hatred: Racism(s) in Europe today. Brussels.

Evola, Julius. 2008. Anticomunismo positivo. Scritti su bolscevismo e marxismo, 1938-1968. Napoli: Controcorrente Ed. Farrant, Andrew; McPhail, Edward, and Sebastian Berger. 2012. Preventing the "Abuses"of Democracy. Hayek, the "Military usurper"and Transitional Dictatorship in Chile? The American Journal of Economics and Sociology 71/3: 513-538.

Femia, Joseph V. 1982. Gramsci's political thought. Hegemony, consciousness and revolutionary process. Oxford: Oxford University Press.

Ferro, Marc. 2010. Le livre noir du colonialisme. Paris: Fayard/Pluriel.

Franke, Berthold. 1988. Die Kleinbürger. Begriff, Ideologie, Politik. Frankfurt a.M.: Campus.

Franklin, Bruce. Ed. 1972. The essential Stalin. Major theoretical writings (1905-1952). Garden City, and New York: Anchor.

Friedman, Milton. 2002. Capitalism and Freedom. Chicago, and London: University of Chicago Press.

Friedrich, Carl J., and Zbigniev Brzezinski (eds.). 1956. Totalitarian Dictatorship and Autocracy. Cambridge/MA: Harvard University Press.

Friedrich, Carl J., Michael Curtis, and Benjamin R. Barber. 1969. Totalitarianism in perspective: three views. London: Pall Mall Press,

Fuëg, Jean-François. 2000. L'anticommunisme des anarchistes. Paris: Ed. du Monde Libertaire et al.

Generalsekretariat zum Studium des Bolschewismus. 1975. Führer durch die bolschewistische und antibolschewistische Literatur. London: Slienger

Giddens, Anthony. 1998. The Third Way. Polity: The Renewal of Social Democracy. Cambridge.

Gills, Barry. 1996. Korea Versus Korea: Political Economy, Diplomacy and Contested Legitimacy. Hoboken: Routledge. Goldthorpe, John Harry et al. Eds. 1968-70. The affluent worker. Cambridge: Cambridge UP, 3 vols.

Gorz, André. 1987. Farewell to the Working Class: An Essay on Post-Industrial Socialism. London: Pluto Press.

Gramsci, Antonio. 2000. The Antonio Gramsci Reader: Selected Writings, 1916-1935. New York: New York University Press.

Greiner, Bernd et al. Eds. 2006-2013. Studien zum Kalten Krieg. Hamburg: Hamburger Edition, 6 vols.

Gross, Bertram. 1980. Friendly Fascism: The New Face of Power in America. New York, M. Evans.

Guérin, Daniel. 1966. La Commune de Paris. Paris: Hachette.

Gurvitch, Georges. 1962. Problèmes de sociologie générale. In Traité de sociologie, ed. Georges Gurvitch, 155-251. Paris: Presses Universitaires de France.

Hall, Peter A., and David Soskice (eds.). 2001. Varieties of Capitalism. The Institutional Foundations of Comparative Advantage. Oxford: Oxford University Press.

Haupt, Heinz-Gerhard. 1979. Die Pariser Kommune. Frankfurt a.M., and New York: Campus.

Hayek 1981a: D9; citation according to Farrant, Andrew; McPhail, Edward \& Berger, Sebastian. 2012. 'Preventing the

"Abuses" of Democracy. Hayek, the "Military usurper" and Transitional Dictatorship in Chile? The American Journal

of Economics and Sociology, Vol. 71, Nr. 3, pp. 513-538, p. 521.

Hegedus, Andras. 1976. Socialism and Bureaucracy. London: Allison, and Busby. 
Hegedus, Andras. 1977. The Structure of Socialist Society. London: Constable.

Heller, Agnes, Ferenc Fehér, and György Markus. 1983. Der sowjetische Weg. Bedürfnisdiktatur und entfremdeter Alltag. Hamburg: VSA.

Hilferding, Rudolf. 1981. Finance Capital. A Study of the Latest Phase of Capitalist Development. London: Routledge, and Kegan Paul. 1904.

Hofmann, Werner. 1967. Stalinismus und Antikommunismus: zur Soziologie des Ost-West-Konflikts. Frankfurt a.M.: Suhrkamp.

Horowitz, David (ed.). 1967. Containment and revolution. Western policy towards social revolution: 1917 to Vietnam. London: Blond.

Hubbard, Ron L. 1956. Scientology. The Fundamentals of Thought. Commerce/CA: Bridge.

Huxley, Aldous (1960), Brave new world: a novel. London, Chatto, and Windus [1932].

Jakowlew, Alexander. 2004. Der Bolschewismus, die Gesellschaftskrankheit des 20. Jahrhunderts. In Das Schwarzbuch des Kommunismus 2, ed. Stéphane Courtois et al., 176-236. München: Piper.

Jorion, Paul. 2013. Lord Turner et la City. Le Monde, Eco \& Entreprise, 9 avril: 2.

Kahan, Vilém. Ed. 1990. Bibliography of the Communist International: 1919-1979. Vol. 1. Leiden et al.: Brill.

Kaplan, Lewis E. 2006. God Bless You Joe Stalin: The Man Who Saved Capitalism. New York: Algora.

Kassis, Wassilis, and Charlotte Schallié. 2013. Nicht wirklich tolerant. Universität Osnabrück, Pressemitteilungen \# 168, 28 June <https://www.uni-osnabrueck.de/presse_oeffentlichkeit/presseportal/pressemeldung/artikel/soziale-vorurteileunter-studierenden.html>

Kenrick, Douglas Moore. 1988. Where Communism Works. The Success of Competitive Communism in Japan. Rutland, Basingstoke Macmillan, and Tokyo: C.E. Tuttle [2nd ed. 1991].

Kiernan, Ben. 2004. How Pol Pot Came to Power: Colonialism, Nationalism, and Communism in Cambodia, 1930-1975. New Haven: Yale University Press. second edition.

Kim, Dschong II. 1984. The Worker's Party of Korea is a Juche type revolutionary party which inherited the glorious traditions of the DIU. Pyongyang (Reprint).

Kornai, János. 1986. Contradictions and Dilemmas: Studies on the Socialist Economy and Society. Harvard: MIT Press.

Kornai, János. 1992. The Socialist System. The Political Economy of Communism. Princeton: Princeton University Press.

Kropotkin, Peter A. 1968. Fields, factories and workshops. New York: B. Bloom.

Kuhn, Thomas S. 1982. The Structure of Scientific Revolutions. Chicago: Chicago University Press [1967].

Kurz, Robert. 1999. Schwarzbuch Kapitalismus. Ein Abgesang auf die Marktwirtschaft. Frankfurt a.M.: Eichborn.

Laski, Harold Joseph. 1933. Democracy in Crisis. London: Allen, and Unwin, and New York: AMS Press? [Reprint 1969].

Lazar, Marc. 2005. Le communisme, une passion française. Paris: Perrin.

Lee, Namhee. 2007. The making of minjung: democracy and the politics of representation in South Korea. Ithaca/NY:

Cornell University Press.

Lefebvre, Henri. 1938. Hitler au pouvoir, bilan de cing années de fascisme en Allemagne. Paris: Bureau d'Éditions.

Lefebvre, Henri. 1965. La proclamation de la Commune. Paris: Gallimard.

Lejeune, Dominique. 2003. La peur du "rouge" en France. Paris: Belin.

van der Linden, Marcel (ed.). 2007. Was war die Sowjetunion? Kritische Texte zum real existierenden Sozialismus. Wien: Promedia.

Lissagaray, Hippolyte Prosper Olivier. 1969. Histoire de la Commune de 1871. Paris: Maspero [1877].

Luff, Jennifer. 2012. Commonsense anticommunism. Chapel Hill/NC: Univ. of North Carolina Press.

Lutz, Burkart. 1984. Der kurze Traum immerwährender Prosperität. Eine Neuinterpretation der industriell-kapitalistischen Entwicklung im Europa des 20. Jahrhunderts. Frankfurt a.M., and New York: Campus.

Luxemburg, Rosa. 1972. Selected political writings. London: Cape, and New York: Grove.

Mannheim, Karl. 1936. Ideology and Utopia. An introduction to the sociology of knowledge. London, and New York: Routledge, and Kegan Paul [1929].

Manutscharjan, Aschot. 2009. Die Gorby-Show. Wendejahr 1989. Der Anfang vom Ende der Sowjetunion. Das Parlament \# 41, 5 October: 23.

Marcou, Lilly. 1988. Stalinismus. In Kritisches Wörterbuch des Marxismus. Eds. Georges Labica et al., vol. 7: 1259-1263. Hamburg: Argument Verlag

Marcuse, Herbert. 1964. The one-dimensional man. Boston/MA: Beacon Press. Studies in the ideology of advanced industrial society.

Martens, Ludo. 1993. Fascisme et anticommunisme. Bruxelles: PTB.

Marx, Karl. 1875. Critique of the Gotha Programme. Gloucester: Dodo Press [reprint 2009].

Marx, Karl. 1871a. Civil War in France <http://www.marxists.org/archive/marx/works/1871/civil-war-france/ch05.htm> [1 April 2013].

Marx, Karl. 1871b. The Paris Commune. London: Sidgwick, and Jackson [reprint 1971].

Marx, Karl, and Friedrich Engels. 1848. The Manifesto of the Communist Party (The Communist Manifesto). Beijing: Foreign Language Press [reprint 1975].

Marx, Karl. 1976. The Capital. Harmondsworth: Penguin, 3 vols. [1867]

Moch, Jules. 1978. Le communisme, jamais ! Paris: Plon.

Montalbano, Giuseppe. 1987. Critica al comunismo. Caltanissetta: Krinon.

Müller, Tim B. 2013. Book review of John Lamberton Harper: The Cold War. H-Soz-u-Kult, 31 May, <http://hsozkult. geschichte.hu-berlin.de/rezensionen/2013-2-154>.

Nolte, Ernst. 1963. Der Faschismus in seiner Epoche. Action française - Italienischer Faschismus - Nationalsozialismus. München: Piper [last ed. 2000].

Nolte, Ernst. 1974. Deutschland und der Kalte Krieg. Stuttgart: Klett-Cotta.

Nolte, Ernst. 1989. Der europäische Bürgerkrieg 1917-1945. Nationalsozialismus und Bolschewismus. Frankfurt a.M.: Propyläen, 4th ed.

Nolte, Ernst, and François Furet. 1998. „Feindliche Nähe": Kommunismus und Faschismus im 20. Jahrhundert. Ein Briefwechsel. München: Herbig Verlag.

Orwell, George. 1945. Animal farm: a fairy story. Harlow: Longman [reprint 1988]. 
Pagès, Max et al. 1979. L'emprise de l'organisation. Paris: PUF [reprint Paris: Desclée de Brouwer 2009].

Palacios, Margarita. 2009. Fantasy and Political Violence: The Meaning of Anticommunism in Chile. Wiesbaden: VS Verlag für Sozialwissenschaften (GW).

Pankratowa, Anna. 1976. Fabrikräte in Rußland. Der Kampf um die sozialistische Fabrik. Frankfurt a.M.: Fischer [\# 1923].

Pareto, Vilfredo. 2006. The Rise and Fall of Elites: An Application of Theoretical Sociology. New Brunswick/NJ: Transaction Publ.

Polanyi, Karl. 1944. The great transformation: [the political and economic origins of our time]. Boston, Beacon Press [reprint 1957].

Polanyi, Karl. 1957. The great transformation: [the political and economic origins of our time]. Boston: Beacon Press [1944]. Postman, Neil. 1999. A Bridge to the Eighteenth Century. New York: Alfred Knopf.

Proctor, Robert N., and Londa Schiebinger (eds.). 2008. Agnotology. The making and unmaking of ignorance. Stanford: Stanford University Press.

Proudhon, Pierre-Joseph. 1969. Selected writings. New York: Doubleday.

Rebatet, Lucien. 1940. Le bolchevisme contre la civilisation. Paris: Nouvelles Études Françaises.

Reitman, Janet. 2011. Inside Scientology: The Story of America's Most Secretive Religion. Boston: Houghton Mifflin.

Right to Food. 2013. http://www.righttofood.org [30 March 2013].

Ruotsila, Markku. 2001. British and American anticommunism before the Cold War. London et al.: Frank Cass.

Ruotsila, Markku. 2005. Churchill and Finland: a study in anticommunism and geopolitics. London: Frank Cass.

Sanders, Alain. 1988. Mes maquis anti-communistes. Maule: Ed. du Présent.

Saxonberg, Steven. 2012. Transitions and Non-Transitions from Communism: Regime Survival in China, Cuba, North Korea, and Vietnam. Cambridge: Cambridge University Press.

Schmeitzner, Mike. Ed. 2007. Totalitarismuskritik von links. Göttingen: Vandenhoeck, and Ruprecht.

Schrecker, Ellen W. 1986. No Ivory Tower: McCarthyism and the Universities. New York: Oxford University Press.

Schreiber, Max. 2013. Xenophobia stretches from the street to the dinner table. Japan Times, May $26<$ http://www. japantimes.co.jp/news/2013/05/26/national/xenophobia-stretches-from-the-street-to-the-dinner-table/>

Schumpeter, Joseph A.: 1928. The Instability of Capitalism. Economic Journal \# 38: 361-386.

Schumpeter, Joseph A.: 1943. Capitalism, socialism and democracy. London: G. Allen, and Unwin.

Schwan, Gesine.: 1999. Antikommunismus und Antiamerikanismus in Deutschland. Kontinuität und Wandel nach 1945. Baden-Baden: Nomos.

Shin, Jin-Wook: 2005. Modernisierung und Zivilgesellschaft in Südkorea. Zur Dynamik von Gewalt und Heiligkeit in der modernen Politik. Wiesbaden: Deutscher Universitäts-Verlag

Sik, Ota. 1976. Third Way: Marxist-Leninist Theory and Modern Industrial Society. London: Wildwood House.

Song, Du-Yul, and Rainer Werning. 2012. Korea - Von der Kolonie zum geteilten Land. Wien: Promedia.

Soros, George. 1998. The crisis of global capitalism, The open society endangered. New York: Public Affairs Publisher

Souvarine, Boris. 1939. Stalin - A Critical Survey of Bolshevism. New York: Alliance Book Corporation, Longmans, Green \& Company [Reprint Kessinger Publishing, 2007].

Suret-Canal, Jean. 2002. Le livre noir du capitalisme. Paris: Le Temps des Cérises.

Swennen, Marc. 2010. Les mouvements anticommunistes dans les années 1920. Bruxelles: CRISP.

Széll, György. 1985. Démocratie et Société en 1984 - L'Allemagne, Orwell et Tocqueville. Bulletin de l'Association Internationale des Sociologues de Langue Française 2: 52-69.

Széll, György. 1992a. Totalitarianism. In Concise Encyclopaedia of Participation and Co-Management. Ed. György Széll, 855-862. Berlin, and New York: de Gruyter.

Széll, György. 1992b. Yugoslavia. In Concise Encyclopaedia of Participation and Co-Management. Ed. György Széll, 981-986. Berlin, and New York: de Gruyter.

Széll, György. 2001. To learn from Japan? European Labour Relations. Ed. György Széll, vol. 2: 191-205. Gower: Aldershot.

Széll, György. 2010a. Changing Labour Relations in China. Indian Journal of Industrial Relations 45/4: 554-565.

Széll, György. 2010b. Modernisierung in (Süd-)Korea - Gewalt und Globalisierung. Sozialwissenschaftliche Literaturrundschau 60: 68-73

Széll, György. 2012. Book review of Song Du-Yul, and Rainer Werning, Korea - Von der Kolonie zum geteilten Land. Zeitschrift Asien 125: 141-143.

Széll, György, and Ute Széll. Eds. 2009. Quality of Life and Working Life in Comparison. Frankfurt a.M. et al.: Peter Lang

Taylor, Frederick W. 1911. The Principles of Scientific Management. Westport/CN: Greenwood Press \& New York, Harper \& Row [1964].

Teodori, Massimo (ed.). 1998. L'anticomunismo democratico in Italia. Firenze: Liberal Libri.

Tetsuo, Hirata, and John W. Dower. 2006. Japan's Red Purge: Lessons from a Saga of Suppression of Free Speech and Thought, originally in Shukan Kinyobi, no. 616, July 28, 2006, translation Japan Focus on July 7, 2007, republished [Zmag.org|Zcommunications.org] 2007) <http://en.wikipedia.org/wiki/Anti-communism\#Japan>.

Thur, Paul. 1937. Aus der Hexenküche des Anti-Bolschewismus. Basel: Verlag Freie Schweiz.

Tito, Josip Broz. 1960. The building of socialism and the role and tasks of the Socialist Alliance of the Working People of Yugoslavia. Belgrade: Socialist Alliance of the Working People of Yugoslavia.

Tosel, André. 2010. Kommunismus. In Historisch-kritisches Wörterbuch des Marxismus. Eds. Wolfgang F. Haug et al., 7/l: 1298-1333, Hamburg: Argument Verlag.

Traverso, Enzo. 2001. De l'anticommunisme. L'histoire du XX' siècle revue par Nolte, Furet et Courtois. L'Homme et la société: 169-194.

Traverso, Enzo (ed.). 2001. Le totalitarisme. Le XXe siècle en débat. Paris: Seuil.

Trotsky, Leon D. 1937. The revolution betrayed. What is the Soviet Union and where is it going? New York: Pathfinder [reprint 1972].

United Nations/Department of Economic und Social Affairs. 1971. Popular Participation in Development. New York: Emerging Trends in Community Development.

Vilmar, Fritz. 1986. Antikommunismus. In Lexikon des Sozialismus. Eds. Thomas Meyer; et al., 30. Köln: Bund Verlag. Vitols, Sigurt. 2002. Shareholder-Value. Risse in der Glitzerfassade. Die Mitbestimmung 11: 21-23.

Wagenknecht, Sahra. 1994. Antisozialistische Strategien im Zeitalter der Systemauseinandersetzung. Bonn: Pahl-Rugenstein. 
Weisz, Bernard. 2011. Une voix communiste. Chauvigny: Escampette

Wikipedia. 2013a. Communism <http://en.wikipedia.org/wiki/Communism> [19 August].

Wikipedia. 2013b. Anti-Communism <http://en.wikipedia.org/wiki/Anti-communism> [30 March].

Wikipedia. 2013c. Anti-Communists <http://en.wikipedia.org/wiki/Category:Anti-communists> [30 March].

Wikipedia. 2013d. Totalitarianism <http://en.wikipedia.org/wiki/Totalitarianism> [2 September].

Wikipedia. 2013e. The Third Way <http://en.wikipedia.org/wiki/Third_Way> [30 March].

Wikipedia. 2013 f. Unification Church/Moon Sect <http://en.wikipedia.org/wiki/Sun_Myung_Moon> [30 March].

Wikipedia. 2013 g. Don Camillo <http://en.wikipedia.org/wiki/Don_Camillo> [27 July].

Wikipedia. 2013 h. Anders Behring Breivik <http://en.wikipedia.org/wiki/Anders_Behring_Breivik> [1 August].

Wright, Lawrence. 2013. Going Clear: Scientology, Hollywood, and the Prison of Belief. New York: Vintage.

Yazawa, Shujiro. 2009. Two interpretations of the Japanese information society - The Japanese information society

at a crossroad. In European Social Integration - A Model for East Asia? Eds. György Széll, et al., 241-254.

Frankfurt a.M. et al.: Peter Lang.

Ziegler, Jean, et al. 2011. The Fight for the Right to Food: Lessons Learned. London: Palgrave Macmillan.

\section{Submit your manuscript to a SpringerOpen ${ }^{\circ}$ journal and benefit from:}

- Convenient online submission

Rigorous peer review

- Immediate publication on acceptance

- Open access: articles freely available online

- High visibility within the field

Retaining the copyright to your article

Submit your next manuscript at $\gg$ springeropen.com 